\title{
Trading silence for a voice: Ethnography of lack for the contemporary classroom
}

\author{
Roger Norum \\ "Let us have the luxury of silence" \\ - Jane Austin, Mansfield Park
}

\section{Whence silence's silence}

Marcus Tullius Cicero is said to have referred to silence as "one of the great arts of conversation". A Roman statesman, lawyer and philosopher, Cicero hailed from a wealthy municipal family of the Roman equestrian order, and is considered to be one of Rome's greatest rhetoricians and stylists of prose. What exactly was Cicero onto? How could silence be so valuable in a society so beset with oration, with articulation, with proclamation, with pronouncement? And more to the purposes and theme of this special issue: what is, or what should be, the role of silence in the toolkit of the ethnographer? What might silence's role be in that of the teaching anthropologist? In this reflection, I think through some of the possible uses of silence in the anthropology classroom.

Curiously, silence has been little studied, either as an entity on its own or alongside other sensory or physical phenomena. This holds even in the field of linguistics - a discipline well-versed in the voicing and un-voicing of lingual utterance - where silence has most often been left out of in-depth scholarly research except perhaps for its role as a boundary-marker denoting the beginning and ending of a statement. Rather, the scholarly tradition of silence has been to "define it negatively—as merely the absence of speech" (Saville-Troike 1982: 117). During the 1970s, ideas about silence in linguistics were closely associated with negativity, passiveness, impotence - even death. Silence was seen to be an absence: absence of speech, absence of meaning and intention, absence of affect (Ephratt 2008). Much of how language has been studied has sought to deny the functions and functioning of silence (Dauenhauer 1980). This comes despite the observation that some 70 per cent of communication is commonly understood to be non-verbal (Knapp 1978; Langer 1942). Yet the human linguistic manifestations of silence are multiple and varied, and include pauses, gaps, lapses, lulls and intervals. Silence in speech can take diverse forms: from the "unnoticed cessation of sound in the production of consonants" (Tannen and SavilleTroike 1985: xvii) to pauses at the beginning or end of an utterance in the stream of speech of speaker, from the ebbs and flows of "lulls" (Goffman 1967) in conversation, to the full, extended silence of one person speaking or not - with another. Michal Ephratt has detailed the roles of what he calls "eloquent silence" - an "iconic affective way of expressing emotions" - across six distinct functions of language (Ephratt 2008: 1909). Such silence is a means chosen by the speaker for significant verbal communication alongside speech; it is not the listener's silence nor the silencing of the speaker. Even meaningful silences can be distinguished between, such as the prosodic gaps, hesitations and pauses that appear in conversations between two or more people. Such "silent communicative acts" may include gestures or other visual cues, and are often heavily dependent on adjacent vocalizations for their meaning, and can serve to "question, promise, deny, warn, insult, request, or command", functioning as intentional, communicative acts in their own right (Saville-Troike 1982: 117, 24). Silence can also play a key role in how authors understand and frame various literary actors, as Patricia Laurence explains in her consideration of the "unsaid", the "unspoken" and the "unsayable" in the work of Virginia Woolf (Laurence 1991). 
In the field of anthropology, Keith Basso's (1970) ethnographic research on the pervasive role of silence among the Apache people in the Southwestern United States is perhaps the best known - or at least the most cited work on the cultural roles of silence. Unsurprising is the fact that Basso found that silence among the Apache typified a variety of contexts, such as respect or bereavement. But Basso also observed silence in contexts distinct from that of surrounding, normative white American society, attesting to the cross-cultural nature of silence. Whereas in Apache society silence occurred when strangers met each other, when couples began courting, or when one returns to a community after a long absence, these situations would elsewhere in the United States frequently be met with avoidance of awkward silences, engaged flirtatious vocal and gesture communication, or celebratory revelry.

In the decades following Basso's work, anthropologists seemed hesitant to take up his work as a (silent) call to arms, engaging little with the phenomena or idea of silence. Only over the past decade or so have scholars returned to the quiet, writing about the role of silence as unsuspicious and active presence embodied in traumatic family pasts (Kidron 2009); wielded in contexts of torture (Whitehead 2012); indicative of violence (Gammeltoft 2016); and embedded within the reconstruction of memories (Navaro-Yashin 2012, Dragojlovic 2015). More recently, silence has been investigated as a looming presence in elderly care homes (Ojanen 2016) and religious communities (Koosa 2016), explicating some of the more overtly banal contexts of silence. Silence has also seen scholarly attention paid to the adverse, affective effects it has on people and places (Kjær 2005). In much of this scholarship, silence is overwhelmingly understood to be a negatively marked absence of something - of speech, of action, of presence, or agency. Such a focus portrays silence as a somehow negative entity that is inflicted upon or taken away from an agent- but not necessarily a meaningful entity created of one's own volition. While agency, power, and the margins are indeed important topics addressed by anthropological studies of silence, there is more that anthropology can add to how silence is understood cross-culturally, and indeed how it might be wielded in cross-cultural settings such as the classroom.

Kidron has attributed the lacuna in any substantive study of silence to the Cartesian tendency of Western scholars to establish logocentric and reductionist binaries, such as absence/presence and silence/voice. Quite simply put, silence is often thought to be no thing, the absence of action (Braithwaite: 321). Many scholars, and much conventional wisdom, seems to consider silence as an unmarked zero-sign (Kjær 2005), one in which silence is not merely a lack of something, but rather no anything at all: a 'non- sense' or a 'nothing' (Kurzon 1998: 5-7). Even scholars who attend to silence's meaning-ness frame it as an absence as opposed to an agentive creation. As Samarin (1965: 115) has noted, "Silence can have meaning. Like the zero in mathematics, it is an absence with a function". While making an important point, the byproduct of understanding voice and silence through such oppositional categorisations is the failure to investigate the complex and multi-faceted aspects of social communication (Kidron 2009: 19). In reality, there is rarely a perceivable black-and-white distinction between pure noise and pure silence, and silence as a communicative concept is indeed much more complex. As Jaworski has put it, "As with all pairs of such oppositions, the boundaries between speech and silence are unclear, indistinct and fuzzy" (Jaworski 1993: 381; see also Jaworski 1997). The very problematisation of silence stems in large part from this logocentric marking of a lack, which, in the context of the "Eurocentric psychosocial norm of voice", eventually requires some form of voiced emancipation (Kidron 2009: 19). Such binary oppositions have regularly been attacked and subsequently deconstructed by a range of cultural theorists (see Irigaray 1985). In much anthropological literature, a silence is most often treated as secrecy, political subjugation, avoidance or repression - all active forms of agentive, if not expressly violent, silencing (Kidron 2009: 6). This may explain the lack of attention in anthropology to silence as a form of communication or expression in its own right, one that does not rely on the normative logic of speech for its own objectification.

But silence is embedded in the practice of anthropology itself, and indeed in the traditional and the contemporary ethnographic toolkit. As James Fernandez (2006) has written, processes of silence and silencing are ever-present in fieldwork, across data collection, interpretation, analysis, writing, editing, publication, and so on. Yet read through your favourite ethnography and you're likely to have to search quite diligently - and maybe even read in between the lines - to find an express focus on given silences. One obvious reason as to why silence often goes undocumented in ethnographic fieldwork is that it simply does not attract attention - except in the most blatantly obvious of situations. Silence is less notable or observable simply because it does not stand out in the way that expressive, conspicuous behaviour does (Saville-Troike 1982: 119). Most ethnographers these days, pace the work of Pink (2009) and others on the senses, also tend to prioritise verbalised knowledge and information gathered by means of sight in lieu of messages received by other senses. This seems to suggest that that which has no voice is either unworthy of explicit ethnographic attention or perhaps that such phenomena is too difficult to actually research in any effective, empirical manner. 
As social scientists we are consumed by words, listening to, decoding and studying what people say and do, and then giving credence and explication (READ: voice) to what those things mean. Even when there are no words, we often try to force words out of people. François Bouchetoux, in a call for new anthropological methods that rethinks the nature of anthropological knowledge and the conditions of human communication, writes that

"words are both pointless and scarce, empty signifiers and fragments of reality put together in an incessant search to complete it ... Can silence be explained? How, and why should one write it? How is she to 'come up with interesting ethnographic details' in an empty Siberian space?"

(Bouchetoux 2014: 41).

To put it another way: if an ethnographer observes a tree falling in a forest, but that tree makes no sound, does she write about it in her field notes? And if so, how? Anthropologists, long been proud of giving a voice to those who have had their voices taken away by the state and other nefarious bodies, are proud of their ability to translate the silence of the Other into voiced (if at times undigestible) academic language for their readership. As Judith Okely puts it, "The anthropologist hardly respects the other's right to remain silent" (Okely 1992: 22). This lack of respect does some degree of violence to the research subject, and indeed, ethnographic publications have tended to favour voiced expression and activity over plosive silences. Yet such understandings of the roles of the voiced and the silenced in anthropology's objects of study may serve to explain the lack of the discipline's attention to silence as a form of communication or expression in its own right, one that does not rely on the normative logic of speech for its own objectification.

Whether as $\mathrm{PhD}$ students or as seasoned researchers venturing out for fieldwork, many of us have felt the frisson of seeing the world anew as we caress the textured covers of our distressed beige Moleskines, soon to be inked full of observations, ideas, quotes and voices. Anthropologists study the language of the field in order to be able to understand what the people in a field say and $d o$ more than we expressly consider what they do not say or do. If we are studying a marginalized community, for example, we may be guided by a moral compass, feeling pride that our work will be able to give some voice to people who silenced by the regimes they live under. Silence in the interview may be meditative, but it is hardly seen to be productive. An MP3 recording full of emptiness and silence is hardly useful to the researcher. Or is it? Returning from a fieldwork trip with a notebook still filled with empty pages would likely to receive blank stares from academic colleagues, to say nothing of demanding questions from the funding body who supported such research. It is not just that the vocal academic has a selfproclaimed duty to voice the research subject through his or her work; it is often necessary for their employment in the first place. This conflict raises ethical issues and questions surrounding the nature of knowledge production. As Neil Whitehead explains, "the establishment of professional ethnographic credentials takes place through the unsilencing of the now 'researched' other", making the results of ethnography out to be ipso facto epistemologically problematic (Whitehead 2012: 227).

Silence in fieldwork carries with it certain paradoxical powers. It is the silent listener who is the judging party, Susan Gal argues, and this agent holds significant power over the person who speaks (Gal 1989: 91). This is the case across many contexts, from job interviews to psychotherapy sessions. In the classroom - and now to the special issue at hand - silence underlies a classroom's unspoken discourses of power, dominance and legitimacy. In many classes, the teacher is the individual who is most often speaking and exposing his or her thoughts; when the other party doesn't respond, the power dynamics are shifted around in an at times uncomfortable way. A silent classroom thus represents one of the few opportunities that students hold and leverage the capacity to reassert the power imbalance in their direction. If it is to the benefit of both students and teachers to make the classroom a space of active and/or passive learning, when students turn the classroom into a silent space by either individually or as a group not speaking, they are thwarting the task and role of the teacher to create an effective space of learning.

\section{References}

Basso, Keith. 1970. “'To Give up on Words': Silence in Western Apache Culture”, Soutbwestern Journal of Anthropology 26(3), 213-230.

Bouchetoux, François. 2014. "Fire”. In: Writing Anthropology: A Call for Uninbibited Methods. New York: Palgrave Pivot. 
Braithwaite, Charles Austin. 1981. Cultural Uses and Interpretations of Silence. Seattle: University of Washington.

Dauenhauer, Bernard P. (ed.) 1980. Silence: The Phenomenon and Its Ontological Significance. Bloomington: Indiana University Press.

Dragojlovic, Ana. 2015. "Affective geographies: Intergenerational hauntings, bodily affectivity and multiracial subjectivities”, Subjectivity, 8(4): 315-334.

Ephratt, M. 2008. “The functions of silence”. Journal of Pragmatics, 40 (11): 1909-1938.

Fernandez, James W. 2006: "Silences of the Field”. In: Maria- Luisa Achino-Loeb (ed.), Silence: The Currency of Power. Oxford: Berghahn, pp. 158-173.

Gal, Susan. 1989. "Between speech and silence: The problematics of research on language and gender", $\operatorname{IPr} A$ Papers in Pragmatics, 3(1): 1-38.

Goffman, Erving. 1967. Interaction Ritual: Essays in Face-to-Face Behavior. Chicago: Chicago University Press.

Irigaray, Luce. 1985. This Sex Which is Not One. Ithaca: Cornell University Press.

Kidron, Carol. 2009. "Towards an Ethnography of Silence: The Lived Presence of the Past in the Everyday Lives of Holocaust Trauma Survivors and their Descendants in Israel", Current Antbropology, 50(1): 5-27.

Kjær, Sarah Holst. 2005. “Silence”, Ethnologia Europaea, 35(1): 141-148.

Knapp, Mark L. 1978. Nonverbal Communication in Human Interaction. New York: Holt, Rinehart and Winston.

Koosa, Piret. 2016. "Evangelical Silence in a Komi Village”. Ethnologia Europaea, 46(2): 58-73.

Kurzon, Dennis. 1998. Discourse of Silence. Amsterdam: John Benjamins Publishing.

Jaworski, Adam. 1993: The Power of Silence: Social and Pragmatic Perspectives. London: SAGE Publications.

Jaworski, Adam 1997. "Introduction: An overview”. In: Adam Jaworski (ed.), Silence: Interdisciplinary Perspectives. Berlin: Mouton de Gruyter, pp. 3-14.

Langer, Susanne. 1942. Philosopby in a New Key. Cambridge: Harvard University Press.

Laurence, Patricia Ondek. 1991. The Reading of Silence: Virginia Woolf in the English Tradition. Stanford: Stanford University Press.

Mehrabian, Albert. 1981. Silent Messages: Implicit Communication of Emotions and Attitudes. Belmont, CA: Wadsworth.

Navaro-Yashin, Yael. 2012. Make-Believe Space: Affective Geography in a Postwar Polity. Durham: Duke University Press.

Ojanen, Karoliina. 2016. "Silences, Old Age and Institutionalized Care”, Etbnologia Europaea, 46 (2).

Okely, Judith 1992: "Anthropology and Autobiography: Participatory Experience and Embodied Knowledge". In: Judith Okely and Helen Callaway (eds), Anthropology and Autobiography. London: Routledge, pp. 1-27.

Pink, Sarah. 2009. Doing Sensory Ethnography. London: SAGE.

Saville-Troike, Muriel. 1982. The ethnography of communication: An introduction. Oxford: Basil Blackwell.

Tannen, Deborah and Saville-Troike, Muriel. 1985. "Introduction” In: Tannen, Deborah and Saville-Troike, Muriel (eds), Perspectives on silence. Norwood, N.J.: Ablex. 
Teaching Anthropology 2020, Vol.9, No. 1, pp.93-97

Whitehead, Neil. 2012. "Ethnography, Silence, Torture and Knowledge", History and Anthropology, 23 (2): 271 282. 